\title{
製紙スラッジを利用した複合ボイラー システム採用の発電プラント
}

丸住製紙秼大江工場 久保田 憲 一

\section{Power Plant with Complex Boiler System Utilizing Paper and Pulp Sludge}

\author{
Kenichi Kubota
}

\begin{abstract}
We have bark, chip, sludge and miscellaneous trash etc, as the industrial waste matters in the paper and pulp mills.

Up to the present in this company slag was incinerated and the others were burnt to generate low presure's steam.

This time, the power plant was set up in the Ōe mill, which adopts the complex boiler system utilizing these waste matters as fuels in the purpose of saving energy and decreasing pollution.
\end{abstract}

This plant has followed the normal course for about one year, since the trial run of it. I want to introduce here the outline of the equipment and operation.

\section{1.はじめに}

紙・パルプ工場では, 産業廃棄物としてバーク, チ ップダスト, スラッジ, 雑ゴミ等がある。今まで当社 ではバーク, ダスト, 雑ゴミはバークボイラーで然烧 して低圧烝気を発生させ, スラッジは焼却処理をして いた。

今回大江工場において，これらを燃料として考え， 燃焼, 高圧蒸気の発生, 発電と省エネルギー・低公害 化を目的とした複合ボイラーシステムを採用し，発電 プラントを設置した。

本プラントは, 運転開始以来順調に稼動して 1 力年 を経過した。以下その概要と運転実績を紹介する。

\section{2. 発電所の設備仕様}

表 $1 ， 2$ の通りである。

\section{3. システムの特徴}

当社大江工場の特色は，一缶・一抄紙機の単一工場 であるために, 工場側の負荷変動がすべてボイラ一, タービンの負荷に影響を及ぼす，といら運転の難かし さを抱えている。安定した運転と負荷変動に対応でき,

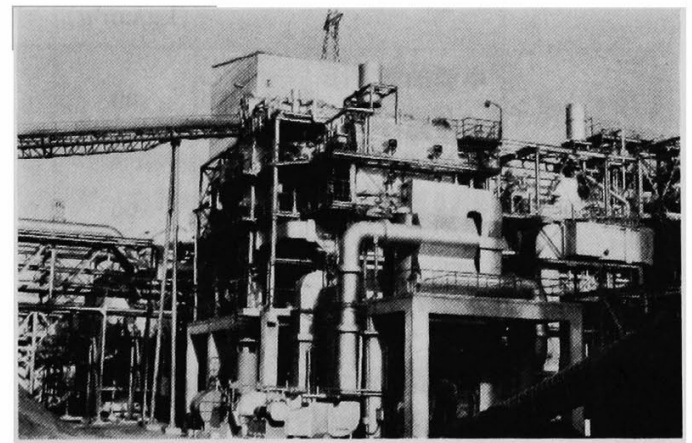

写真 1 発電プラント外観

1 連続操業が可能となることを前提とし, 本プラント の計画に充分考慮した。

スラッジは安定燃焼, 脱具のできる流動焼却炉を, またバーク, 雑ゴミ等に石, 鉄片が混入したものの然 焼と流動炉の燃焼ガスの熱回収をするためストーカボ イラーを採用した。なお, 燃焼ガス中に含まれている $\mathrm{HCl}$ による高温腐食の防止のためストーカボイラーは 高圧飽和ボィラーとした。

3.1 スラッジ燃焼に流動炉の採用

製紙スラッジは水分が多いため, 従来は投棄又は重 
表 1 ボィラー設備

\begin{tabular}{|c|c|c|c|c|c|c|c|}
\hline 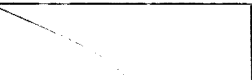 & & & 氛 気 & 件 & & & 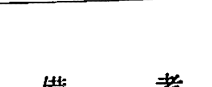 \\
\hline & 式 & $\begin{array}{l}\text { 蒸発量 } \\
(\mathrm{t} / \mathrm{h})\end{array}$ & $\begin{array}{l}\text { 蒸気压力 } \\
\left(\mathrm{kg} / \mathrm{cm}^{2} \mathrm{~g}\right)\end{array}$ & $\begin{array}{l}\text { 蒸気温度 } \\
\left({ }^{\circ} \mathrm{C}\right)\end{array}$ & 燃烧 方式 & 然 & 備 \\
\hline 1 号重油ボイラー & 単胴故射形 & 107 & 103 & 500 & $\begin{array}{l}\text { タンゼンシャル } \\
\text { ファイアリング }\end{array}$ & $\begin{array}{c}\mathrm{C} \text { 重 油 } \\
(\mathrm{N} \text { 分一 }-0.24 \%)\end{array}$ & $\begin{array}{r}\mathrm{NO}_{x} 150 \mathrm{ppm} \\
\mathrm{OF} \mathrm{A}+\mathrm{GM}\end{array}$ \\
\hline $\begin{array}{r}2 \text { 号ストーカ } \\
\quad \text { ボイラー }\end{array}$ & 二胴水管式 & 32 & 112 & 飽和 & $\begin{array}{l}\text { 往復動式 } \\
\text { ストーカー }\end{array}$ & $\begin{array}{lll}\text { ダ } & \text { ト } \\
\text { バ } & \text { ク } \\
\text { 雑 } & \Xi & \text { ミ }\end{array}$ & $\mathrm{NO}_{x} 150 \mathrm{ppm}$ \\
\hline スラッジ焼却炉 & 流動床炉 & - & - & - & 流 動 床 & 泥 & - \\
\hline 3 号重油ボイラー & 単胴放射形 & 170 & 103 & 500 & $\begin{array}{l}\text { タンゼンシャル } \\
\text { ファイアリング }\end{array}$ & $\begin{array}{c}\mathrm{C} \text { 重 油 } \\
(\mathrm{N} \text { 分一 }-24 \%)\end{array}$ & $\begin{array}{l}\mathrm{NO}_{x} 118 \mathrm{ppm} \\
\mathrm{OFA}+\mathrm{GM} \\
+\mathrm{PM} M \text { バーナー }\end{array}$ \\
\hline
\end{tabular}

表 2 タービン設備

\begin{tabular}{|c|c|c|c|c|c|c|c|c|}
\hline \multirow[b]{2}{*}{$\checkmark$} & \multirow{2}{*}{ 型 } & \multirow{2}{*}{$\begin{array}{l}\text { 出 力 } \\
(\mathrm{kW})\end{array}$} & \multicolumn{2}{|r|}{ 蒸 } & 気 & \multicolumn{2}{|l|}{ 件 } & \multirow{2}{*}{$\mid \begin{array}{c}\text { 回 転 速 度 } \\
\text { タービン/発電栋 }\end{array}$} \\
\hline & & & $\underset{\left(\mathrm{kg} / \mathrm{cm}^{2} \mathrm{~g}\right)}{\text { 入口压力 }}$ & $\underset{\left({ }^{\circ} \mathrm{C}\right)}{\lambda\left(\mathrm{S}^{\circ} \text { 度 }\right.}$ & \begin{tabular}{|} 
抽気圧力 \\
$\left(\mathrm{kg} / \mathrm{cm}^{2} \mathrm{~g}\right)$
\end{tabular} & $\begin{array}{l}\text { 混気圧力 } \\
\left(\mathrm{kg} / \mathrm{cm}^{2} \mathrm{~g}\right)\end{array}$ & $\begin{array}{l}\text { 排気圧力 } \\
\left(\mathrm{kg} / \mathrm{cm}^{2} \mathrm{~g}\right)\end{array}$ & \\
\hline 1号タービン & $\begin{array}{l}\text { 単筒抽気背圧 } \\
\text { 减速機付 }\end{array}$ & 14,500 & 99 & 497 & 6.5 & - & 3.8 & $7,033 / 3,600$ \\
\hline 2 号タービン & 単筒混压復水 & 39,000 & 99 & 497 & - & 3.5 & - & $3,600 / 3,600$ \\
\hline
\end{tabular}

油助然によって狫却されていた。種類は初沈, 凝沈, 活性と多く, 焼却方法も違っていた。しかし,この難 然性物質を約 $700^{\circ} \mathrm{C}$ で流動している砂の中に投入する と，スラッジの燃焼と同時に臭気成分も然焼する。流 動媒体の熱容量が大きいため, スラッジの性状及び水 分の変動に対しフレキシブルで, 常に安定した然焼が できる等を主眼として，流動床炬を採用した。

\section{2 バーク, チップダスト, 雑ゴミ燃焼にストー} カボイラーの採用

バーク, チップダスト, 雑コミの然焼には, 移動火 格子, スプレッダー, 浮遊などの燃燒装置が考えられ る。石まじりで大きさが, 数 $\mathrm{cm}$ から $2 \mathrm{~m}$ 位までのば らつきのある,゙ーク, 水分が変動し, 細かく軽いダス トや石, 鉄片等が混入している雑ゴミ, 幅広い然料を
無選別に投入しても燃焼でき, 然焼時間を简単に調整 できる駆動機構で, 物がつまりにくく，焼損の少ない ストーカーを採用した。

\section{3 高温腐食防止のためにストーカボイラーは飽 和蒸気ボイラーを採用}

流動床炬からの混入排ガス及びストーカボイラーの 然焼排ガス混合ガスには, 高温腐食の原因となる $\mathrm{HCl}$ が含まれている。その対策としてストーカボイラーは 発電用重油ボイラーと同圧力の飽和䳮気ボイラーとし た。発生蒸気は発電用重油ボイラーに導き, 発電用重 油ボイラー発生蒸気と共にここで $103 \mathrm{~kg} / \mathrm{cm}^{2} \cdot 500$ ${ }^{\circ} \mathrm{C}$ の過熱蒸気にするシステムを採用することで，高 温腐食の発生防止に配虑した。 


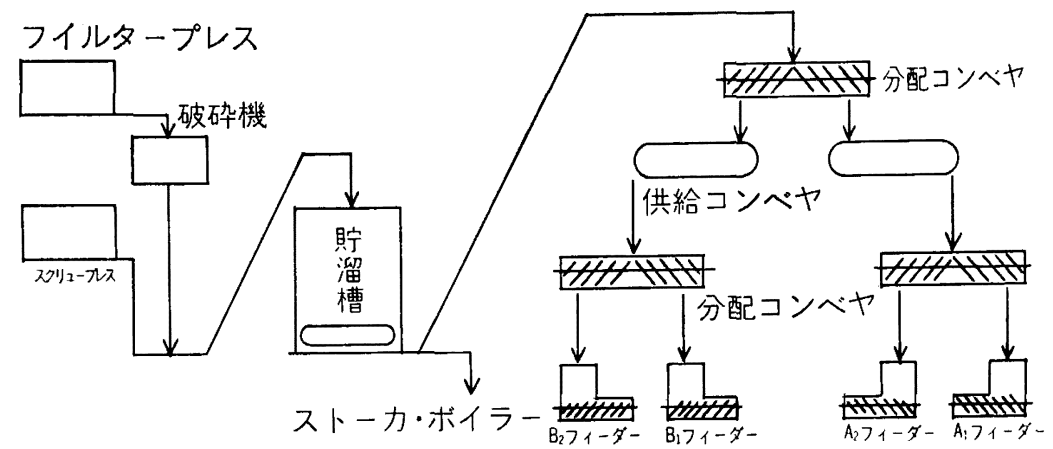

図 1 スラッジのフロ一線図

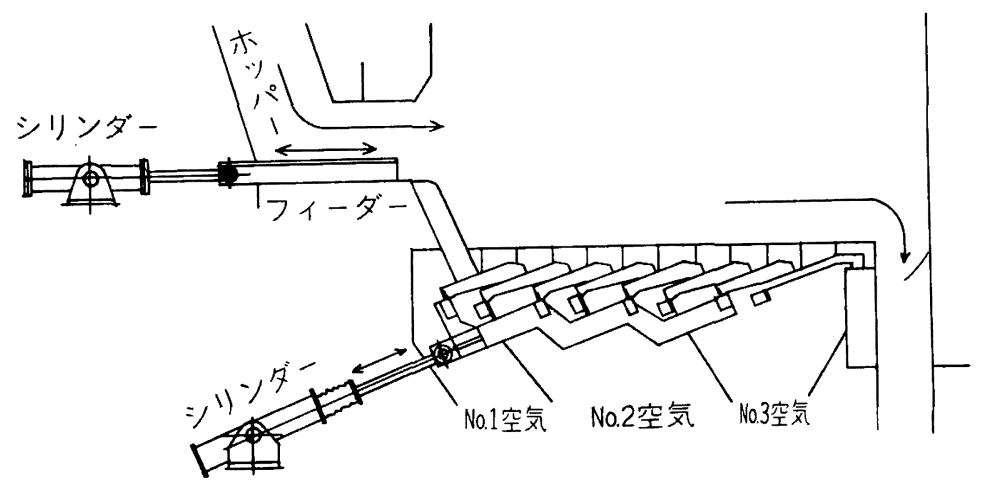

図 2 ストカー構造略図

\section{4 ストーカボイラーが休転しても蒸気を安定供} 給できる重油ボイラー

ストーカボイラーからの飽和蒸気は重油ボイラーの 発生蒸気と混合し, 重油ボイラーの過熱器で $500^{\circ} \mathrm{C} ま$ で過熱して蒸気タービンへ送気する。ストーカボイラ 一と重油ボイラーとを分けることによって, ストーカ ポイラーの修理で停止した場合でも，工場の必要蒸気， 電力が確保できるようにした。

\section{5 抄紙機に紙切れがあっても出力一定運転可能 な発甜設備}

1 号タービンの抽気蒸気・排気蒸気は，ほとんど抄 紙機で使用する。抄紙機が紙切れを起こした場合，排 気蒸気は急激に減少するために, 一般的には排気压高 で大気放出をさせ，必要電力を確保しなければならな い。しかし，本プラントでは，同時に設置した 2 号タ 一ビンの 2 段ブリードにこの余剩蒸気を導き発電し， 電力の安定供給と省エネを行っている。

\section{4. 複合ボイラー発電システムのフロー}

フィルタープレスを出たスラッジは，破破機を通り
小さく破かれ，スクリュープレスのスラッジと一緒に なり贺溜槽に入る。貯溜槽にはダンパー・エプロンフ ィーダーを設けており, 必要量切り出され, メリック で計量し流動炉に供給される。

図 1 に示す経路で $\mathrm{A}_{1}$ フィーダーより $\mathrm{B}_{2}$ フィーダ 一まで必要量分配する。各フィーダーでは炉内の状態 を見ながら適当量投入する。流動炉では 16 本の助然 用重油バーナーが入っており，砂の温度が約 $700^{\circ} \mathrm{C}$ に なるようにしている。その中にスラッジが入り然焼し， 流動炬出口温度は約 $900^{\circ} \mathrm{C}$ になりストーカボイラーの 燃堵室に入る。

ストーカボイラーにはスキップホイストが有り，こ の中にバーク, ダスト, 雑ゴミ, スラッジを投入し, ホッパーまで持ち上げる。余剒のダストはダストサイ ロへ入れ, 必要量切り出され, ベルトコンベヤでホッ パーに入れる。

ホッパー内には，炉内ガスが吹き出さない程度に燃 料を入れている。これは通常運転の 6 時間分である。 ホッパー下部にはフィーダーがあり，これでホッパー 内部の物を炉内に送る（図 2)。 
1 電気集じん機

表 3 公害防止設備

\begin{tabular}{|c|c|c|c|c|c|}
\hline 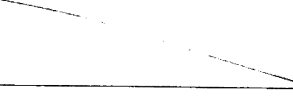 & 式 & $\begin{array}{c}\text { 処理ガス量 } \\
\left(\mathrm{Nm}^{3} / \mathrm{h}\right)\end{array}$ & $\mid \begin{array}{c}\text { 処理ガ } \\
\left({ }^{\circ} \mathrm{C}\right)\end{array}$ & $\begin{array}{l}\text { 出口ばいじ } \\
\text { ん量 } \\
\left(\mathrm{g} / \mathrm{Nm}^{3}\right)\end{array}$ & $\begin{array}{c}\text { 集しん効率 } \\
(\% \text { \% }\end{array}$ \\
\hline 1,2 号ボイラーE P & 乾 式 横 型 & 136,000 & 161 & 0.05 & 99.0 \\
\hline 3 号ボイラーE P & 乾 式 横 型 & 165,000 & 160 & 0.05 & 80.0 \\
\hline
\end{tabular}

2 排煙脱硫装置

\begin{tabular}{|c|c|c|c|c|c|}
\hline 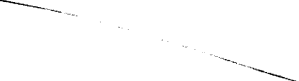 & 式 & $\begin{array}{l}\text { 排ガス量 } \\
\left(\mathrm{Nm}^{3} / \mathrm{h}\right)\end{array}$ & $\begin{array}{c}\text { 排ガ } \\
\left({ }^{\circ} \mathrm{C}\right)\end{array}$ & $\begin{array}{l}\text { 脱硫効率 } \\
(96)\end{array}$ & 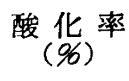 \\
\hline 1，2号ボイラー排脱 & 湿式マグネシウム吸収法 & 161,000 & 68 & 90.5 & 83 \\
\hline 3 号ボイラー排脱 & 湿式マグネシウム吸収法 & 175,000 & 68 & 91.0 & 83 \\
\hline
\end{tabular}

3 煙 突

\begin{tabular}{|c|c|c|c|c|c|c|c|}
\hline & 型 式 & ${ }_{(\mathrm{m})}^{\text {高 }}$ & 外筒材質 & 内筒材質 & 頂 部 径 & 備 & 考 \\
\hline 発電ボイラー用 & R C 内筒式 & 185 & R C & F R P & $\phi 2.8$ & 内筒を & 設可能 \\
\hline
\end{tabular}

フィーダーの往復する回数を調整し，燃料投入舅を 加減している。炉内にはステップグレードストカーが あり，その上に然料を投入する。ステップグレードス トーカーは, 一列おきにストーカーが往復運動し, ス トーカー上の物を移動さす。この時然料はほぐされ, 撹拌されながら燃焼する。大きい物や燃えにくい物が 入ると, フィーダー, ストーカーの往復する回数を減 らせば充分焼却できる。

燃焼室では，ストーカボイラーで然焼したガスと， 流動炉から出るガスが一緒になりボイラーバンクに入 る。バンクを出たガスは, 䬦炭器, 空気予, 熱器を通り, 1 号ボイラーの排ガスと一緒になって電気集じん機に 入る。電気集じん機でばいじんを除去されたガスは, 排䙳脱硫装置で硫黄酸化物を吸収除去され，185 m の 高煙突より大気に排出される（表 $3 \cdot 1,2,3) 。$

ボイラー給水は低圧給水加熱器, 高圧給水加熱器を 通り, 重油ボイラー, スラッジボイラーに分かれて給 水する。スラッジポイラーを出た $114 \mathrm{~kg} / \mathrm{cm}^{2}$ の飽和 蒸気は, 重油ボイラーの汽水ドラムに入り, 重油ボイ ラーで発生した飽和蒸気と一緒に過熱器に入る。 500 ${ }^{\circ} \mathrm{C}$ に過熱された蒸気は 1 号タービンに入り, 抽気 6.5 $\mathrm{kg} / \mathrm{cm}^{2}$ - 排気 $3.8 \mathrm{~kg} / \mathrm{cm}^{2}$ として取り出し, 中圧䔩気,
低圧蒸気として工場に送る（図 3 ）。

\section{5. 運転の実績}

54 年末に運転を開始以来, 1 力年余りを経過した。 スラッジの水分量は当初の計画が $70 \%$ に対して, 実 績では $65 \%$ 位まで脱水が可能となったため, 流動床 炬の重油助然量も少なく安定した運転ができている。 ストーカボイラーにおいても, ストーカーの摩耗, 燃 損による事故もなく順調である。

\section{1 脱水率向上による重油の隇少}

スラッジの水分が $70 \%$ から $65 \%$ に脱水率が向上. したため, 流動床炣内で乾燥予熱に必要な重油助然量 が減少できた。水分が多いとベッド温度が低下するた めに, 最低温度 $\left(600^{\circ} \mathrm{C}\right)$ を設定してベッド温度を一定 に保つよらに, 重油の助然量を制御している。

\section{2 流動砂の隇少対策}

当社川之江工場では $11 \mathrm{t} /$ 月 $\mathrm{BD}$ の流動烧却炉を運 転している。流動砂については造粒により $1 \sim 2 \mathrm{t} /$ 月 程度抜き出しているが, 本プラントでは川之江工場と 比べて, 活性スラッジだけでなく, 初沈・凝沈・活性 スラッジを混烍している。このため䒜機賈が多く，よ り造粒するものと考えていた。しかし，現実には $20 \mathrm{t} /$ 


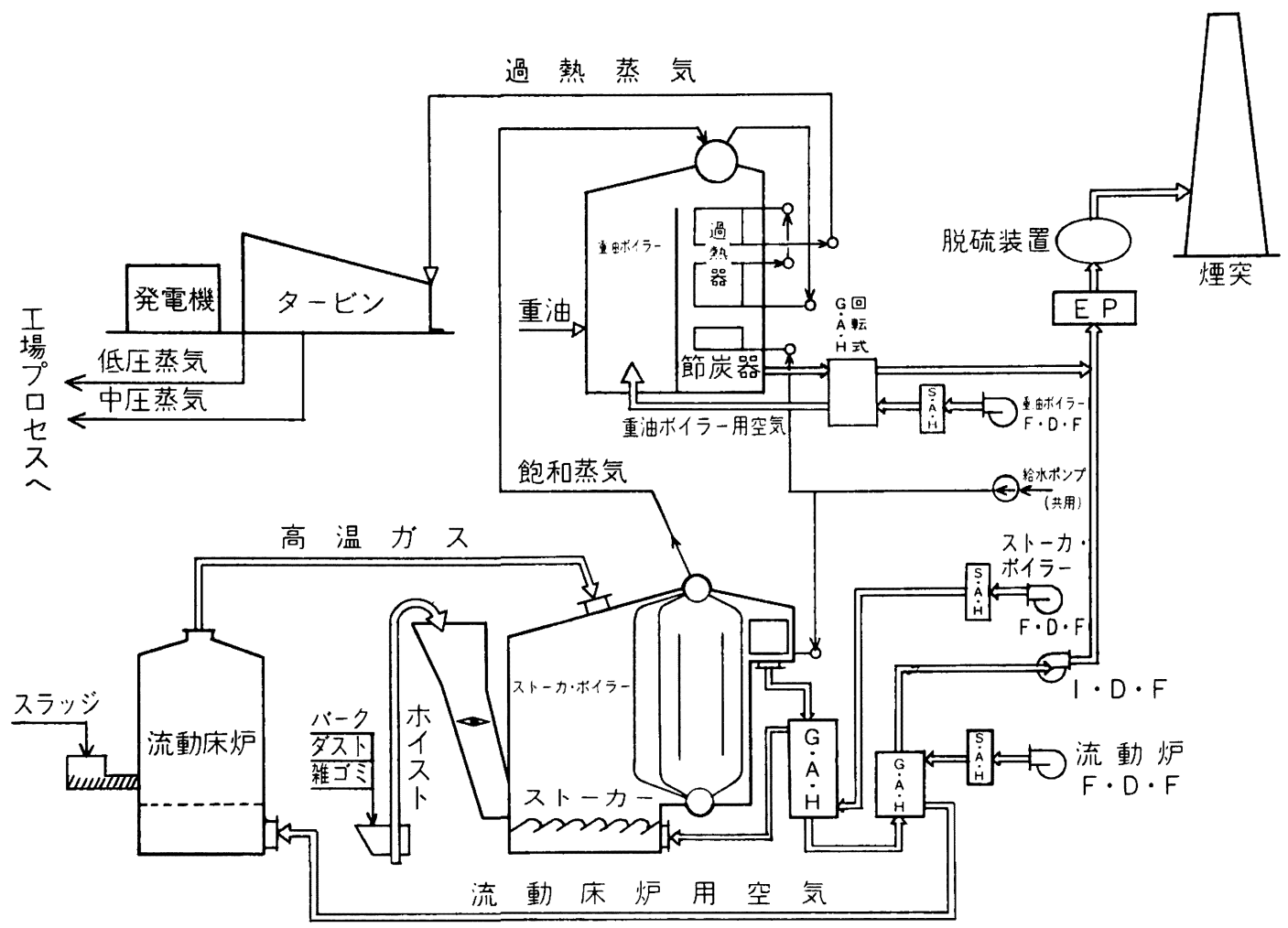

図 3 複合燃料を使用した複合ボイラー発電システムフロー

月の流動砂を投入した。建設時流動砂は珪砂 4 号・5 号を $50 \%$ ずつ入れて運転をしたが減少するので，下 記に示す作業を行った。

1）初期投入と同じで，粒径の小さい 5 号砂を取り やめる。

2）粒径は同じで，産地の違ら砂の投入。

3）運転方法の見直し。

4）粒径が小さく, 耐火度, 熱ショックの強い物に 変更した。

今後も検討を加えて砂の減少を極力少なくして, $5 \mathrm{t} /$ 月程度までにしたいと考えている。

\section{3 ストーカーの這転状態}

バーク, チップダスト, 雑ゴミ等は, 川之江工場で 燃やしていた物と, 性状・成分共同じであり, 想像し ていた小石, 砂, 番線などストーカーに害する物が多 数あった。ステップグレードストーカーは最初の計画 通り，この 1 年間砂や針金のかみ込みは全くなく問題 を起こしていない。ビニールによるストーカーの焼損 を恐れていたが, 定検時の分解点検では異常が見られ
なかった。

\section{4 蒸気及び発電}

抄紙機が紙切れを起こした場合は, 工場送気量の 80 \%が減少する。しかし，電力はほとんど変動しないた めに, 减少による余剩蒸気を，2 号タービンの 2 段ブ リードに混入して発電量を一定に保ち，大気放出を最 小限で運転している。パルプ製造設備の蒸気使用量は わずかであるが，多くの電力を消費する。この設備の 電力使用量は, 工場全体の $60 \%$ 以上を占めており, 負荷変動は 2 号タービンの出力と買電一定制御をかけ て運用している。

\section{6.あとがき}

従来, 脱水後焼却あるいは埋立てられていたスラッ ジを，当社では発電プラントの熱源の一部として利用 し，省石油型発電所を建設した。現在好調に稼動中で あり，スラッジ燃焼に対して流動炉の採用が莫気など に対応でき，工場の安定操業も確保されているので， このシステムの採用は成功であったと考える。 